\title{
Fractional Yield, Extract Composition and Variability from Jordanian Oil Shales
}

\section{Hani M. Alnawafleh ${ }^{1}$, Feras Y. Fraige ${ }^{1,2}$, Khalid E. Tarawneh ${ }^{3}$, Ibrahim A. Sarairah ${ }^{4}$, Laila A. Al-Khatib ${ }^{1,5}$}

${ }^{1}$ Faculty of Engineering, Al-Hussein Bin Talal University, Ma'an, Jordan

${ }^{2}$ Al-Muzahmiayah Branch, Faculty of Engineering, King Saud University, Riyadh, Kingdom of Saudi Arabia

${ }^{3}$ Faculty of Engineering, Isra University, Amman, Jordan

${ }^{4}$ Faculty of Science, Al-Hussein Bin Talal University, Ma'an, Jordan

${ }^{5}$ Naif Arab University for Security Sciences, Riyadh, Kingdom of Saudi Arabia

Email: ^hanialnawafleh@ahu.edu.jo

How to cite this paper: Alnawafleh, H.M., Fraige, F.Y., Tarawneh, K.E., Sarairah, I.A. and Al-Khatib, L.A. (2016) Fractional Yield, Extract Composition and Variability from Jordanian Oil Shales. Journal of Analytical Sciences, Methods and Instrumentation, 6, 51-63.

http://dx.doi.org/10.4236/jasmi.2016.63007

Received: August 10, 2016

Accepted: September 13, 2016

Published: September 16, 2016

Copyright $\odot 2016$ by authors and Scientific Research Publishing Inc. This work is licensed under the Creative Commons Attribution International License (CC BY 4.0).

http://creativecommons.org/licenses/by/4.0/

\begin{abstract}
Surface and subsurface oil shale (OS) rocks in Jordan have potential economic value for the country and still unutilized. This research paper focuses on central and southern OS deposits in Jordan. Brief characterization of four OS deposits is presented. Size distribution test and elemental analysis were performed. Shale oil was extracted via three solvation methods: Soxhlet extraction, extraction via mixing and stirring, and lastly super-critical fluid extraction. Major shale oil fractions were obtained from extract fractionation on chromatographic column. The nuclear magnetic resonance spectroscopy technique was used to study qualitatively the fractional composition of OS extract. Results show that all studied OS deposits have quite similar trend in their particle size distribution and their elemental composition. These OS deposits are found to be varying in their solvation behavior, fractional yield, and shale oil composition. Highest yield is obtained from polar solvents. The OS extraction via solvation processes is promising under certain extraction conditions such as super-critical conditions. The solvation variability of Jordanian OS indicates that different extraction techniques suit different OS deposits. Such variability should be considered in any future extraction options.
\end{abstract}

\section{Keywords}

Jordan, Oil Shale, Solvent Extraction, Variability, Fractional Yield

\section{Introduction}

Jordan has few conventional resources of oil and natural gas, and its energy is largely 
depends on imported resources from neighboring countries. Therefore, Jordan could save much of its imported energy by utilizing its oil shale reserves. The most important oil shale deposits in Jordan are of Late Cretaceous to early Tertiary age [1] [2]. Jordanian OS is kerogen-rich bituminous limestone [3]. The Jordanian oil shale properties vary from one deposit to another indicating that different extraction techniques suit different OS deposits [3] [4].

The most important OS deposits in Jordan are located in central Jordan such as El-Lajjun, Sultani, Attarat Umm Ghudran and Wadi Maghar [5]. The future of OS in Jordan is still uncertain and most of the studies conducted so far on Jordanian oil shale have focused on El-Lajjun OS deposit. The organic content of El-Lajjun OS deposit varies laterally and vertically [3] [4]. The central Jordan OS has the highest average oil content. However, relatively high sulphur content is reported [6]. Based on Jaber et al. [7] and Jaber and Probert [8], the sulphur content is $7 \%$ to $9 \%$ of the organic matter (OM) content and the oil yield from Jordanian OS is up to $10 \%$.

There are wide utilization options for OS resources. Among these options are pyrolysis, combustion, and extraction techniques. Solvent extraction techniques have attracted many researchers over the last three decades. Several solvent extraction methods have been developed for the extraction of shale oil with organic solvents. Among these methods are Soxhlet extraction, ultrasonic extraction, and super-critical extraction (e.g. [9]-[18]). Pyrolysis is reported to be the most effective known method used to extract the oil contained in shales [19]. Different controlling parameters are found to influence the shale oil extractability. Among these factors are particle size, temperature, solventfeed ratio and the mixing intensity [20]. The quantity of solvent used is also considered as a critical factor [15] [21].

A study by Alnawafleh and Fraige [18] shows that solvent extraction is preferable to be conducted under super-critical conditions, and the solvent extraction technique when applied on Jordanian oil shale could be potential under certain extraction parameters. This research paper covers OS deposits from central and southern Jordan, and aims to study their solvation variability. The focus will be on certain parameter controlling their solvation behavior. Fractional yield and shale oil composition are also considered.

\section{Material and Methodology}

\subsection{Sample Preparation and Characterization Procedures}

Oil shale samples were provided from four major oil shale locations in central and southern Jordan (Figure 1). Full sample preparation methodology and characterization experiments were presented in Alnawafleh and Fraige [22] [23]. Analyses performed covered OS petrography, mineralogy, organic carbon content, and Fisher assay. Size distribution test was carried out at Al-Hussein Bin Talal University. A laboratory scale jaw crusher was used to reduce the size of oil shale samples. The crushed OS then fed to a ball mill for 10 mins. After sieving the ground OS, retained OS masses were recorded and the size distribution curves for each sample then constructed. 


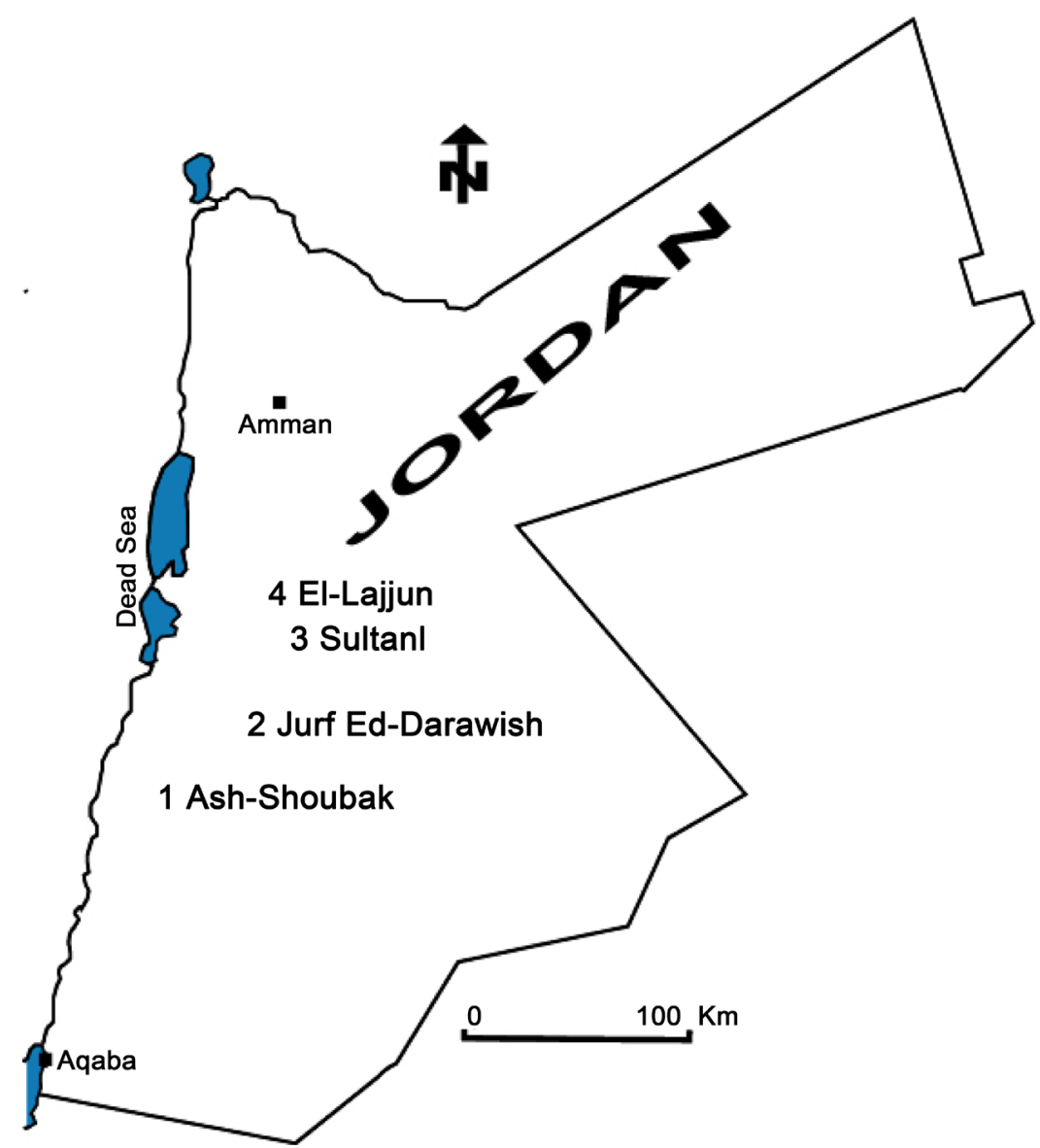

Figure 1. Location of the studied oil shale deposits in central and southern Jordan.

The average elemental composition $\%$ of the total solid samples was analyzed using EuroVector elemental analyzer model: EA 3000 A available at AL al-Bayt University, Jordan.

\subsection{Shale Oil Extraction Procedures}

Shale oil solvent extraction was carried out in three solvation protocols: Soxhlet extraction, extraction via mixing and stirring, and lastly super-critical fluid extraction via extraction reactor designed locally for this purpose (see Alnawafleh and Fraige, 2015a). The purpose is to compare the performance of extraction between them. Eleven different solvents and two solvent mixtures were used in the extraction experiments. Solvent mixture one (Mix. 1) is THF (50\%); Acetone (50\%), whereas, solvent mixture two (Mix. 2 ) is Chloroform (50\%); Acetone (30\%); Methanol (20\%).

In the Soxhlet extraction, four grams of finely comminuted oil shale were transferred to a thimble which was then placed in the Soxhlet chamber $(100 \mathrm{ml})$. The Soxhlet chamber was fitted to a distillation flask containing $200 \mathrm{ml}$ of the extraction solvent. Each extraction run was carried out for $24 \mathrm{hrs}$. Extraction via mixing and stirring involves stirring the OS sample on magnet hot plate at $1000 \mathrm{rpm}$ using $200 \mathrm{ml}$ of solvent. The stirred sample then filtered. Supercritical extraction involves shale oil extraction via the 
designed reactor and relatively high pressure and temperature conditions. Within the reactor, OS sample and solvent used are charged and the pressure and temperature are raised to the desired values. In all protocols, the extraction solvent was separated form liquor via rotary evaporator and the extract was then dried under a stream of N2 gas. The organic matter $(\mathrm{OM})$ yield was then determined.

\subsection{Extract Fractionation}

Chromatographic column of silica gel and alumina $(1.3 \mathrm{~cm}$ i.d., $70 \mathrm{~cm}$ height $)$ was used to fractionate the obtained extract from Soxhlet extraction using solvent Mix. 2. The $30 \mathrm{~g}$ of silica gel layer used in the column is placed in the lower part of the chromatographic column while the $10 \mathrm{~g}$ of alumina layer, in the upper part of the column. Measured quantity of $0.25 \mathrm{~g}$ of oil extract was added to the top of the column and eluted sequentially by $100 \mathrm{ml}$ of hexane, $75 \mathrm{ml}$ chloroform-hexane mixture (2:1), and $70 \mathrm{ml}$ ethanol to separate aliphatic, aromatic and NSO fractions respectively.

\subsection{Nuclear Magnetic Resonance Spectroscopy}

High performance of digital NMR spectrometer in CDCl3, Model: Bruker $300 \mathrm{MHz}$ / Switzerland was used to study qualitatively the fractional composition of oil shale extract.

\section{Results and Discussion}

\subsection{Material Characterization and Grain Size Distribution}

The characterization of the studied oil shales; their mineralogy, composition, texture and quality are reported in Alnawafleh and Fraige [22] [23]. A brief summary is presented in Table 1 . The studied oil shales differ in their organic matter content. Their

Table 1. Summary of the studied oil shale's properties. Table constructed based on data reported by Alnawafleh and Fraige [22].

\begin{tabular}{|c|c|c|c|c|c|}
\hline Oil shale & Sample type & $\begin{array}{c}\text { Organic } \\
\text { matter \% }\end{array}$ & $\begin{array}{l}\text { Component } \\
\text { summary }\end{array}$ & $\begin{array}{l}\text { Internal texture } \\
\text { summary }\end{array}$ & $\begin{array}{c}\text { Fisher assay } \\
\text { summary }\end{array}$ \\
\hline Ash-Shoubak & $\begin{array}{l}\text { Soft } \\
\text { bituminous } \\
\text { chalk marl }\end{array}$ & 05.40 & Significant & Very fine-grained & \\
\hline Juf Ed-Darawish & $\begin{array}{l}\text { Very soft } \\
\text { bituminous } \\
\text { marl }\end{array}$ & 09.50 & $\begin{array}{l}\text { amounts of } \\
\text { organic matter; } \\
\text { Calcite is the } \\
\text { major mineral }\end{array}$ & $\begin{array}{l}\text { matrix, strongly show } \\
\text { flow structure and } \\
\text { consists mainly of } \\
\text { muddy material of }\end{array}$ & $\begin{array}{l}\text { Different oil } \\
\text { yielding capacities; } \\
\text { Highest for Lajjun } \\
\text { and Sultani OS; }\end{array}$ \\
\hline Sultani & $\begin{array}{l}\text { Hard } \\
\text { bituminous } \\
\text { limestone }\end{array}$ & 16.40 & $\begin{array}{l}\text { phase, minor } \\
\text { quartz } \\
\text { content, traces } \\
\text { of fluorapatite }\end{array}$ & $\begin{array}{l}\text { cryptocrystalline } \\
\text { micrite; Cretaceous } \\
\text { forams are abundant. } \\
\text { Brown organic matter }\end{array}$ & $\begin{array}{l}\text { Lowest for } \\
\text { Ash-Shoubak and } \\
\text { Jurf Ed-Darawish } \\
\text { OS }\end{array}$ \\
\hline El-Lajjun & $\begin{array}{l}\text { Very hard } \\
\text { bituminous } \\
\text { limestone }\end{array}$ & 17.50 & and smectite & fills pore spaces & \\
\hline
\end{tabular}




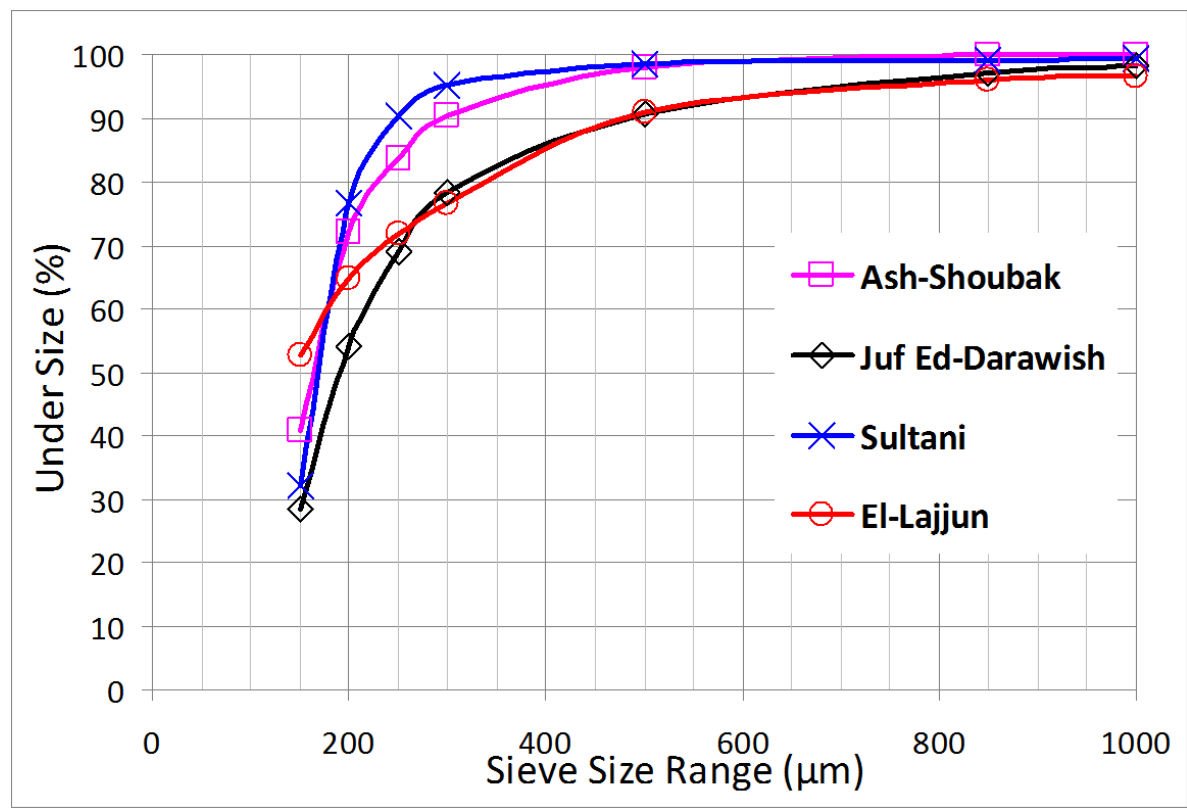

Figure 2. Grain size distribution curve for Jordanian oil shales from four different localities.

mineralogy and internal texture are quite similar. Slight differences are present from one location to another. Their oil yielding capacities are quite different.

Grain size distribution of OS samples from four OS deposits is shown in Figure 2. Results show that $80 \%$ of all studied samples sizes are less than $350 \mu \mathrm{m}$. All deposits reveal quite similar trend but different size distributions. This is normal due to their chemical and physical variability.

\subsection{Elemental Composition}

The average elemental composition \% of the total solid samples calculated from duplicate analyses results is presented in Figure 3. All OS deposits show quite similar distribution for the determined four elements. Highest percentage is obtained from El-Lajjun deposit, whereas the lowest is for Juf Ed-Darawish OS deposit. The elemental composition values are higher than that reported for Egyptian OS by Al-Alla and Nassef [24] from Al-Quseir area. Quite high sulfur content in El-Lajjun OS may limit its future exploitation.

\subsection{Solvent Type Effect}

The effect of solvent type on the shale oil extractability is shown in Figure 4 and Figure 5 , respectively. The OM yields obtained from different solvents used are clearly unequal for the studied oil shales. The most effective extraction solvent is THF. Highest yield is obtained from polar solvents. This is consistent with the results reported by Shawaqfeh and Al-Harahsheh [14]. Solvation yield can be enhanced using solvent mixtures rather than using pure solvents [18]. The type of solvent used is reported to play a significant effect on the yield and the composition of the obtained oil [25]. The quantity of solvent used in the extraction is also very important factor [24]. A study by Tamimi and Uysal 


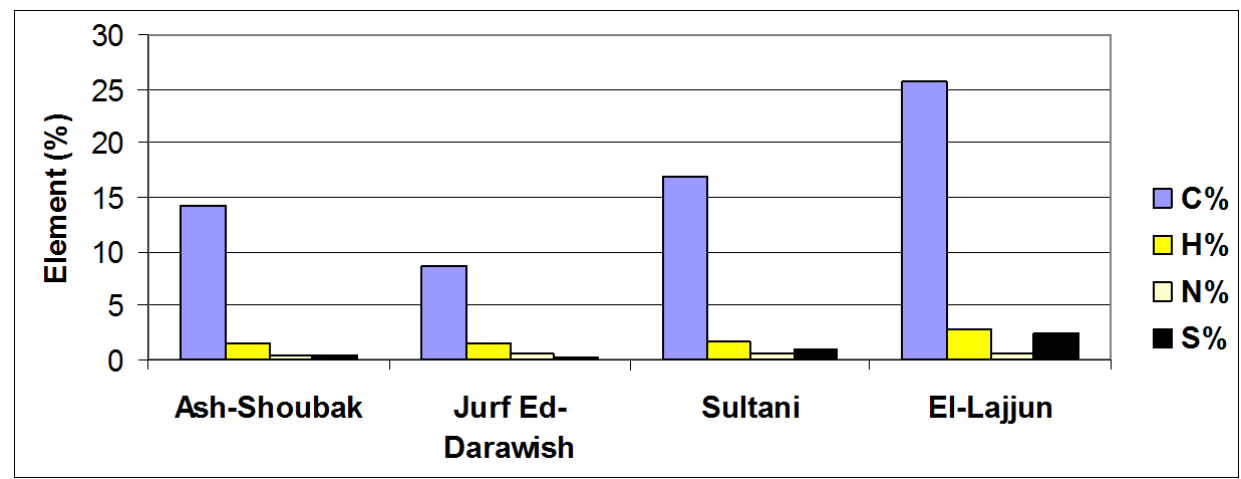

Figure 3. Average elemental composition $\%$ of the total solid samples.

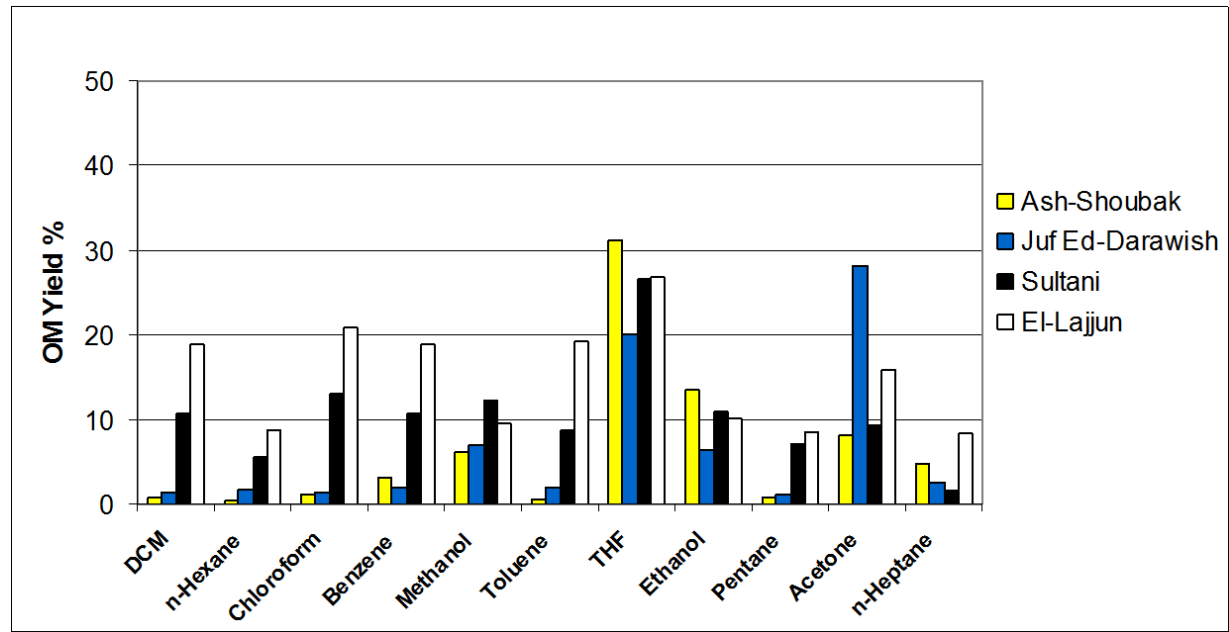

Figure 4. Organic matter $(\mathrm{OM})$ yield \% of different solvent types via Soxhlet extraction for 24 hrs; grain size $<150 \mu \mathrm{m}$.

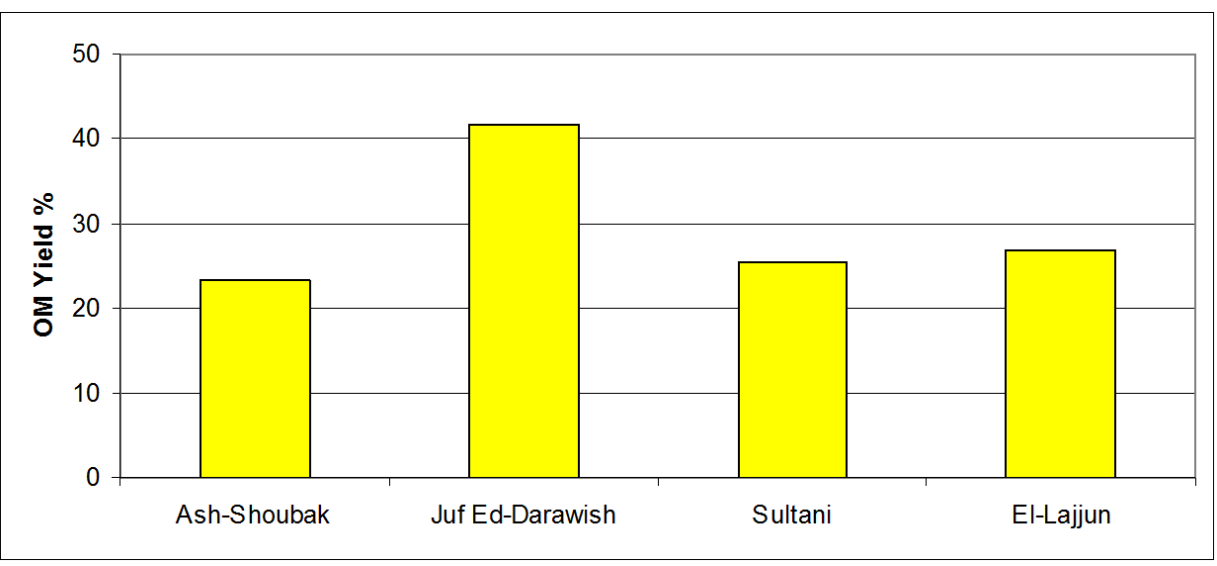

Figure 5. Organic matter (OM) yield \% of solvent Mix. 2 (Chloroform (50\%); Acetone (30\%); Methanol (20\%)) via Soxhlet extraction for $24 \mathrm{hrs;}$ grain size $<150 \mu \mathrm{m}$.

[9] on Jordanian OS showed that the best extraction is obtained when the ratio of solvent to oil shale is in the order of 1:2. Since four OS deposits are studied, it is important to mention that the type of OS for each deposit as well as its original OM and type has 
clear effect on the extraction yield.

\subsection{Grain Size Effect}

The effect of grain size on shale oil extractability is shown in Figure 6 and Figure 7, respectively. Results show that grain size has minor effect on OM yield. Results are consistent with that reported by Anabtawi and Uysal [15]. Grain size effect on shale oil extractability is indicated from the OM yield fluctuation on different grain sizes. The OM yield via soxhlet extraction is found to be high when compared with that of mixing and stirring extraction. The suitable size for extraction is reported to be depends on the extraction kinetics, dissolution thermodynamics, and the mode of mass transfer from the particles [9].

\subsection{Mixing Time Effect}

The effect of stirring time on shale oil extractability is shown in Figure 8. The OM yield

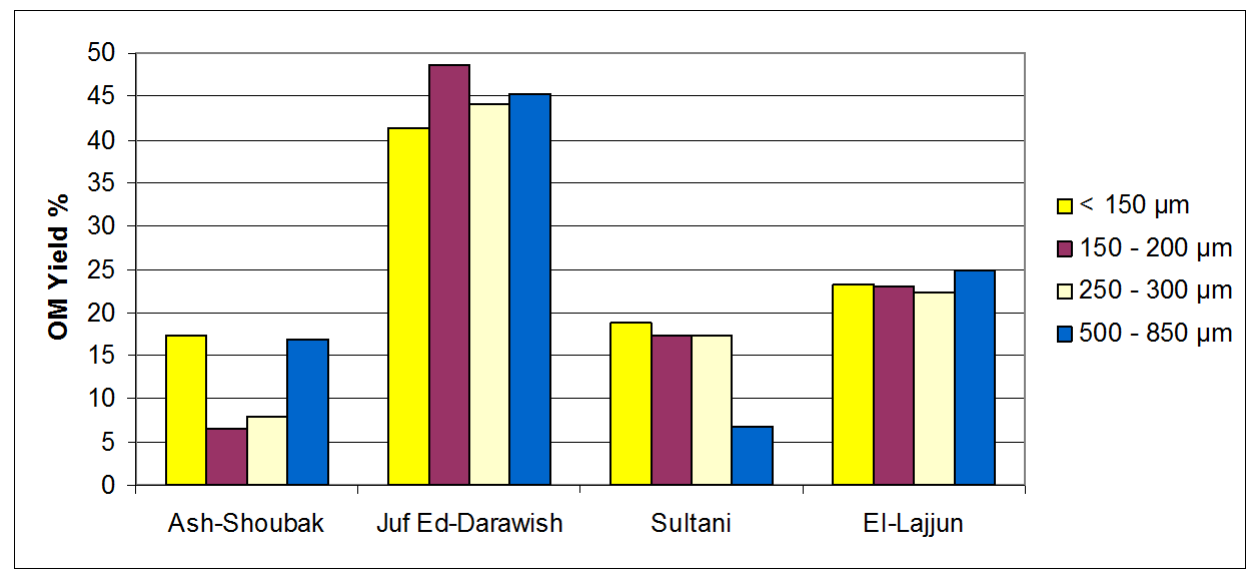

Figure 6. Effect of grain size on $\mathrm{OM}$ yield using solvent Mix. 1 via stirring for 10 mins at $50^{\circ} \mathrm{C}$ and $1000 \mathrm{rpm}$.

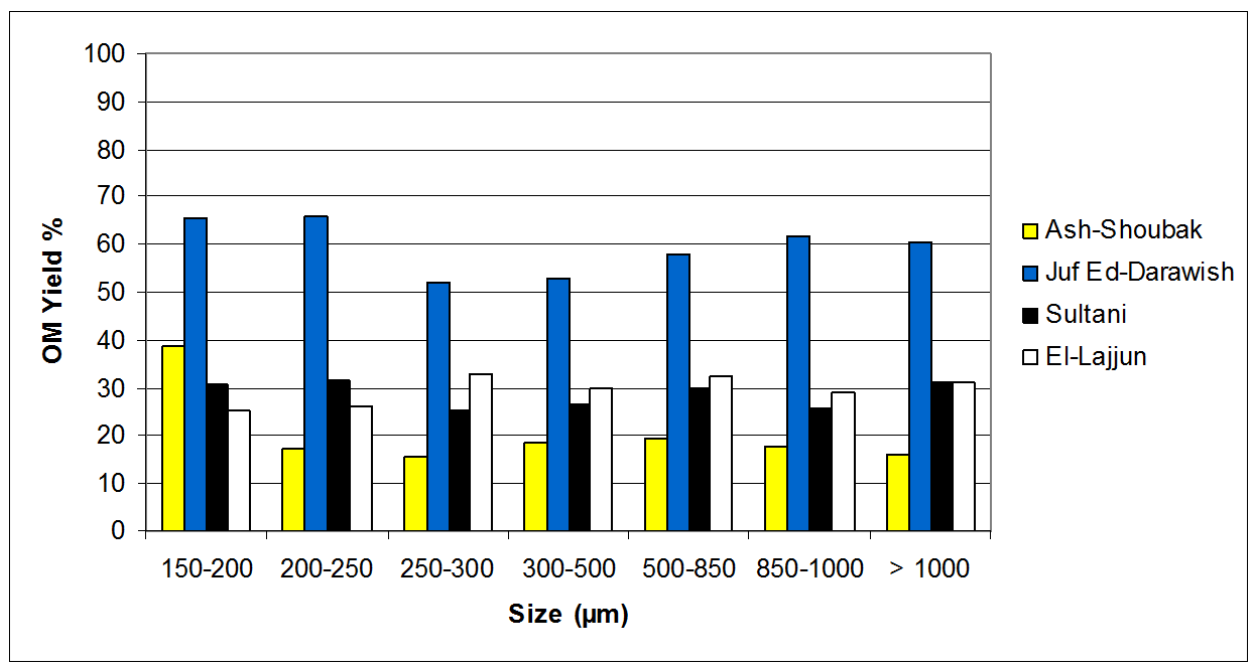

Figure 7. Effect of grain size on OM yield using solvent Mix. 1 via Soxhlet extraction for 24 hrs. 


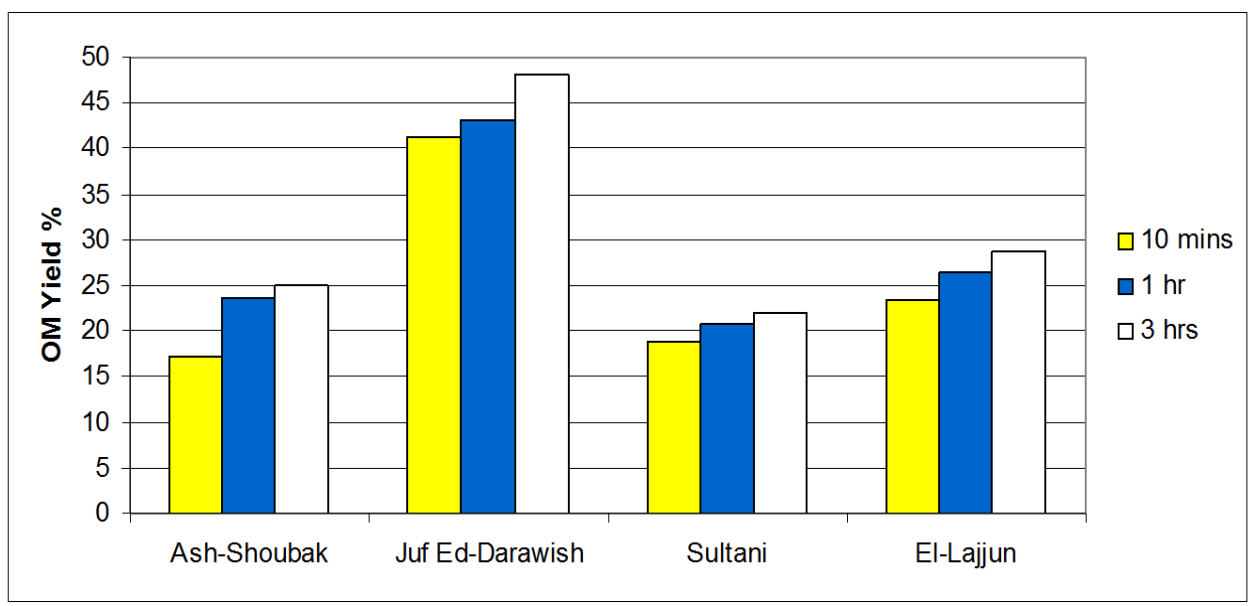

Figure 8. Effect of stirring time on $\mathrm{OM}$ yield using solvent Mix. 1 via stirring at $50^{\circ} \mathrm{C}$ and 1000 rpm, grain size.

shows slight increase with the increase in mixing time. This is due to the dissolving of shale oil during the early stages of contact between solvent and OS material. After enough extraction time, the extraction completed and the ultimate yield will be achieved. Mixing improves the extraction yield due to increasing agitation and turbulence. The effectiveness of mixing on extraction depends on several factors include the rate of mixing, the design of the mixer, the mode of operation, and the solvent to oil shale ratio [9].

\subsection{Heating Temperature Effect}

The effect of extraction temperature on shale oil extractability is shown in Figure 9 and Figure 10, respectively. Generally, the OM yield increases with temperature increase. Significant OM yield is obtained using solvent mixtures under super-critical conditions for both El-Lajjun and Sultani OS deposits compared with the OM yield obtained from traditional methods of shale oil extraction (Figure 10). Super-critical conditions are preferred to be used in the field of shale oil extraction [9] [14] [17] [18].

\subsection{Shale Oil Composition}

Shale oil composition obtained from column chromatography fractionation is shown in Figure 11. Results show that shale oil composition differs from one deposit to another. The aliphatic hydrocarbons are obtained from El-Lajjun and Ash-Shoubak shale oils. With exception of that of Sultani, the aromatic fraction content is generally greater than aliphatic fraction content. All deposits are quite rich in the NSO in their shale oils. High residue fraction is obtained from Juf Ed-Darawish shale oil. The NMR analysis results are presented in Figure 12 and Table 2 respectively. Variability in shale oil composition is clearly indicated. The $1 \mathrm{H}$ NMR spectra of the extracted fraction from all OS deposits show saturated aliphatic and aromatic hydrocarbons. Unsaturated hydrocarbons (alkenes and alkynes) are found in shale oil obtained from Ash-Shoubak and Juf Ed-Darawish oil shales. 


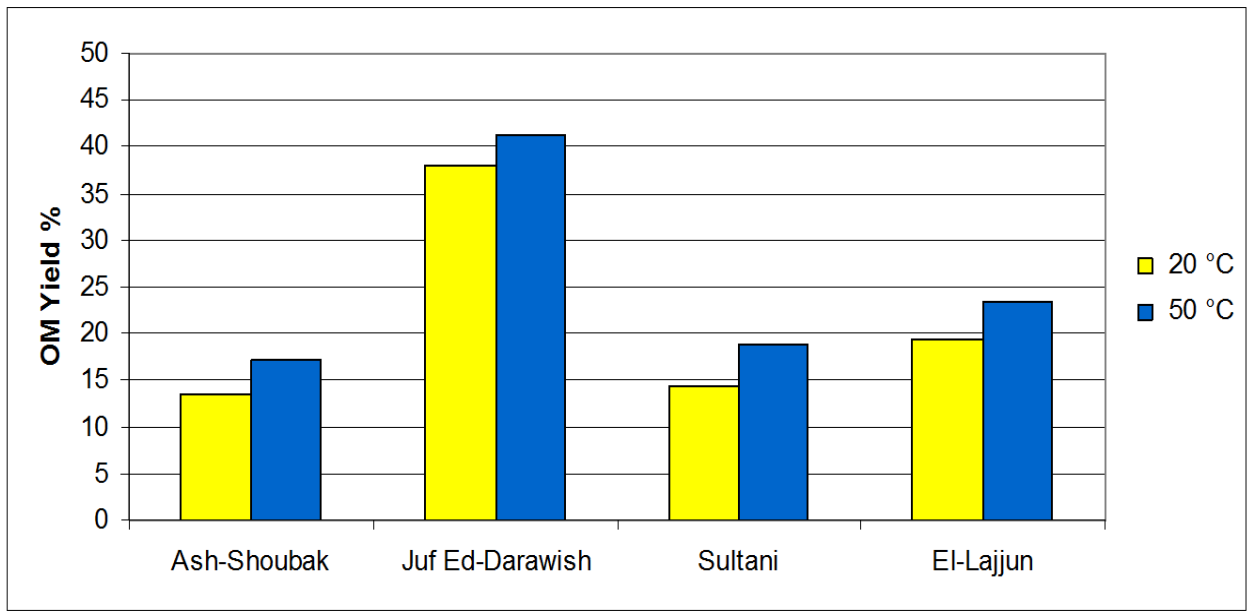

Figure 9. Heating temperature effect on OM yield using solvent Mix. 1 (THF-Acetone mixture 1:1) via stirring at $1000 \mathrm{rpm}$ for $10 \mathrm{mins}$.

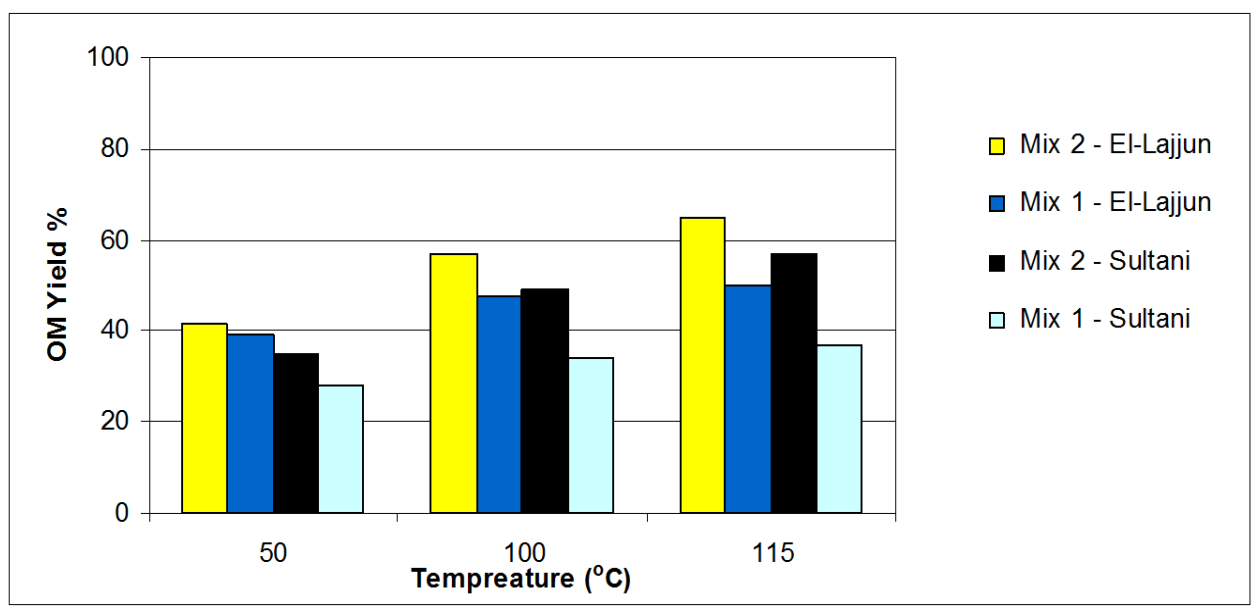

Figure 10. Shale oil yield increase under supercritical conditions via the designed reactor using solvent Mix. 1 and Mix. 2 at elevated temperature and increased mixing rate. Internal reactor pressure is 5 bars. Grain size $<150 \mu \mathrm{m}$. Extraction time: 10 mins.

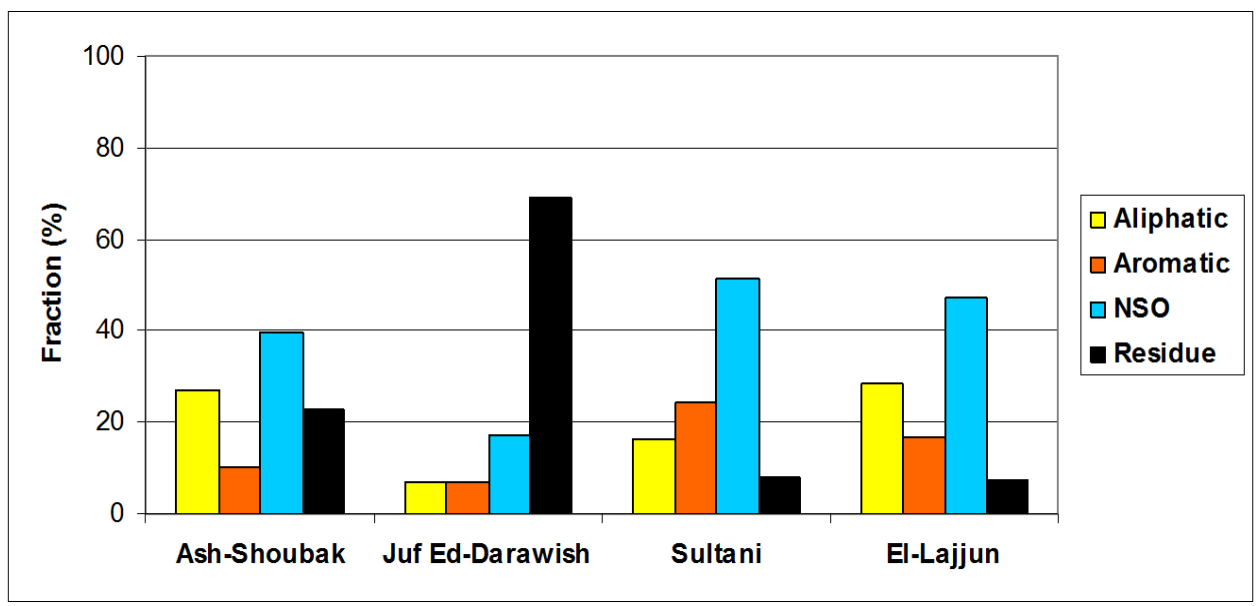

Figure 11. Shale oil content composition (\%). 
(a)

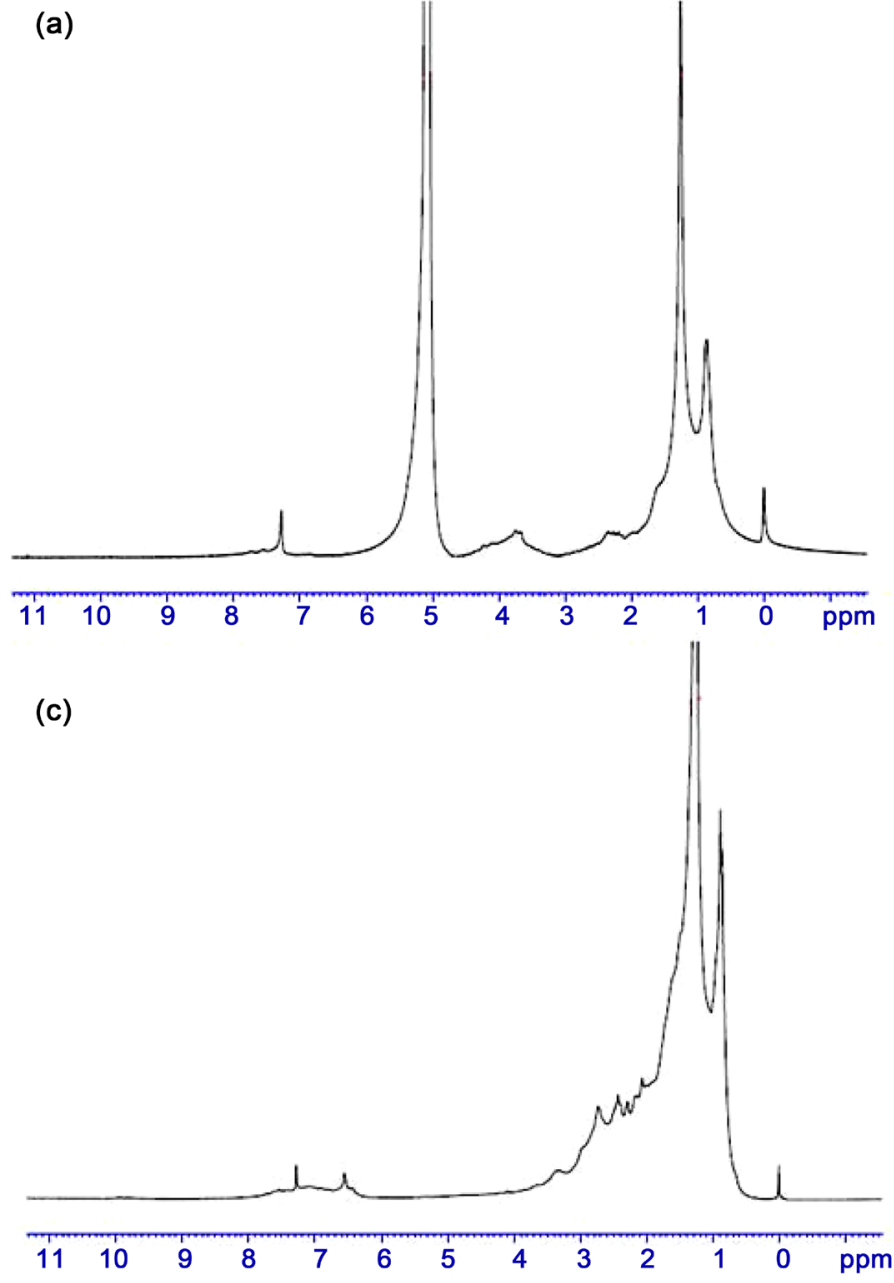

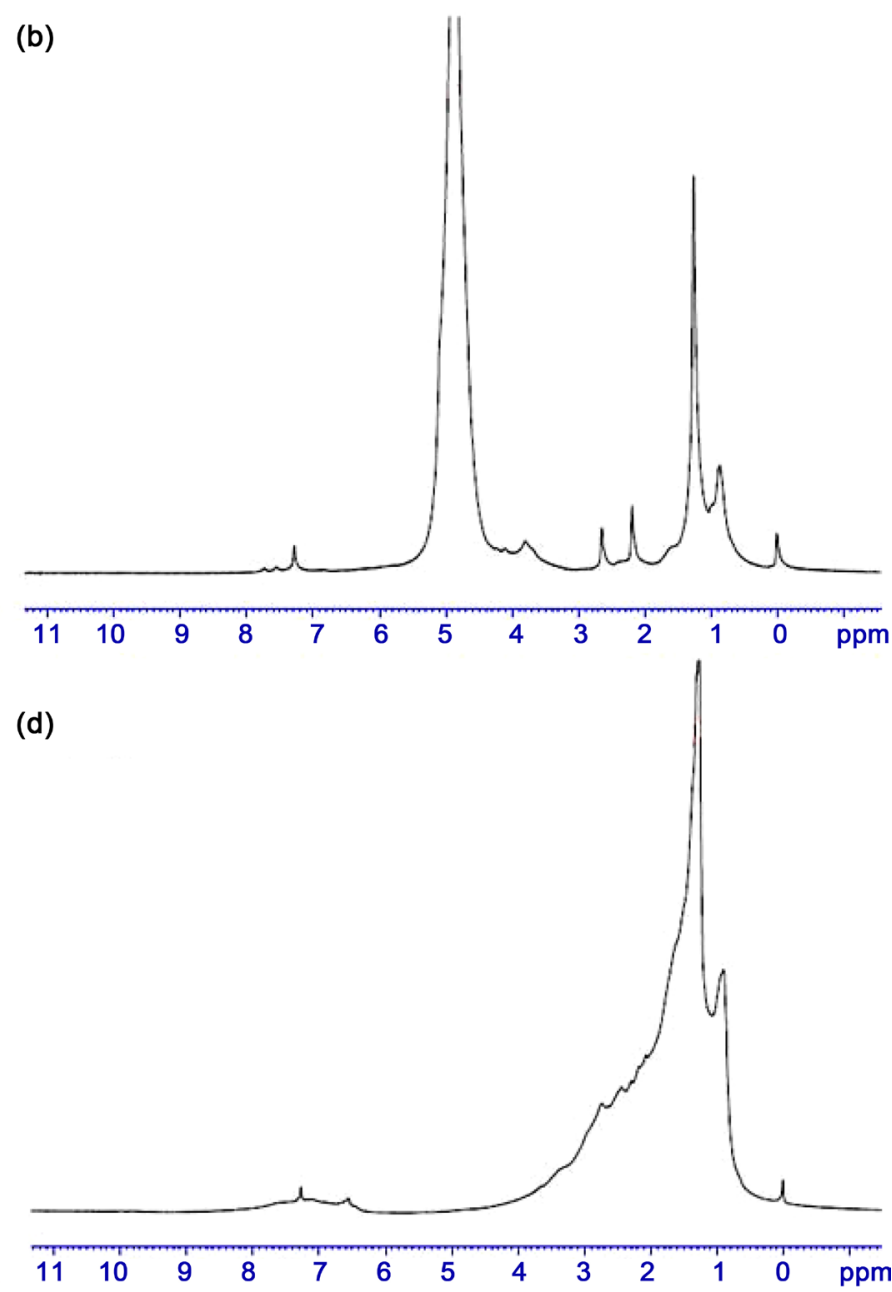

Figure 12. ${ }^{1} \mathrm{H}$ NMR spectra (CDCl3) of extracted shale oil by Soxhlet extraction: (a) Ash-Shoubak. (b) Juf Ed-Darawish. (c) Sultani. (d) El-Lajjun.

Table 2. Summary of the NMR analysis results.

\begin{tabular}{|c|c|c|}
\hline Oil shale & Shale oil composition & Range on ${ }^{1} \mathrm{H}$ NMR spectra \\
\hline \multirow[t]{2}{*}{ Ash-Shoubak } & $\begin{array}{l}\text { Saturated (alkanes) and unsaturated } \\
\text { hydrocarbons (alkenes and } \\
\text { alkynes) - High }\end{array}$ & $\begin{array}{c}0.25-2.16 \mathrm{ppm} \text { for saturated hydrocarbons and } \\
\text { at } 4.80-5.85 \mathrm{ppm} \text { for unsaturated } \\
\text { hydrocarbons }\end{array}$ \\
\hline & Aromatic compounds-Trace & at $7.0-7.8 \mathrm{ppm}$ \\
\hline \multirow[t]{2}{*}{ Juf Ed-Darawish } & $\begin{array}{l}\text { Saturated hydrocarbons and } \\
\text { unsaturated hydrocarbons-High }\end{array}$ & $\begin{array}{c}\text { At } 0.45-2.24 \mathrm{ppm} \text { for saturated hydrocarbons } \\
\text { and at } 4.0-5.84 \mathrm{ppm} \text { for unsaturated } \\
\text { hydrocarbons }\end{array}$ \\
\hline & Aromatic compounds-Trace & At $7.0-7.5 \mathrm{ppm}$ \\
\hline \multirow{2}{*}{ Sultani } & Saturated compounds (alkanes) & At $0.020-3.20 \mathrm{ppm}$ \\
\hline & Aromatic compounds-Trace & At $6.45-7.25 \mathrm{ppm}$ \\
\hline \multirow{2}{*}{ El-Lajjun } & Saturated hydrocarbons only & At $0.21-3.65 \mathrm{ppm}$ \\
\hline & Aromatic compounds-Trace & At $6.57-7.50 \mathrm{ppm}$ \\
\hline
\end{tabular}


Shale oil compositional variability results obtained from this study supported by the physical and chemical OS variability reported in literature, e.g. Alnawafleh et al. [4], indicate that different extraction techniques suit different OS deposits, and such variability should be considered in any future utilization of OS resources in Jordan. The extracted shale oil refinery, therefore, will require special facilities. Accordingly, the economic and environmental aspects of shale oil extraction in Jordan should be highly considered.

\section{Conclusion}

In this paper, a study of the fractional yield, shale oil composition and solvation variability from four OS deposits in Jordan is presented. Results show that the oil shales of AshShoubak, Juf Ed-Darawish, Sultani, El-Lajjun from Jordan reveal quite similar trend in their size distributions and their elemental composition. These OS deposits have different solvation properties. Their solvation behavior is controlled by many factors such as OS type and OM content, extraction method and design, solvent type and quantity, heating temperature, and mixing rate and time. Particle size has minor role. They also show variation in their fractional yield and their shale oil composition. The extraction of Jordanian OS via solvation processes is promising under certain extraction conditions. Potential use of such methods is under super-critical conditions. High OS sulfur content, and the solvation variability should be considered in any future extraction techniques. The economic and environmental aspects of shale oil extraction in Jordan should be highly considered.

\section{Acknowledgements}

This research project is funded by the Al-Hussein Bin Talal University (Research fund \#6/2009) and The Scientific Research Support Fund (\#E/2/23/2008) of the Ministry of Higher education and Scientific Research in Jordan. The authors also thank Miss Khulood Al-Hasanat, Miss Dalal Al-Salameen, and Mr Mohannad Massad for their assistance during the lab work.

\section{References}

[1] Abed, A.M. (2000) The Geology of Jordan and İts Environment and Water. Publication of the Jordanian Geologists Association, Amman, Jordan. (İn Arabic)

[2] Dyni, J.R. (2005) Geology and Resources of Some World Oil-Shale Deposits. Scientific Investigations Report 5294, USGS.

[3] Alnawafleh, H.M. (2007) Geological Factors Controlling the Variability of Maastrichtian Bituminous Rocks in Jordan. PhD Thesis, The University of Nottingham, Nottingham, UK.

[4] Alnawafleh, H.M., Fraige, F.Y., Al-khatib, L.A. and Dweirj, M.K. (2015) Jordanian Oil Shales: Variability, Processing Technologies, and Utilization Options. Journal of Energy and Natural Resources, 4, 52-55. http://dx.doi.org/10.11648/j.jenr.20150404.11

[5] Alali, J. (2006) Jordan Oil Shale, Availability, Distribution, and Investment Opportunity. The NRA, Jordan, No. rtos-A117.

[6] Bsieso, M.S. (2006) Jordan's Experience in Oil Shale Studies Employing Different Technol- 
ogy. Proceedings of the 26th Oil Shale Symposium, Golden, CO, 16-20 October 2006, 20 p.

[7] Jaber, J.O., Probert, S.D. and Williams. P.T. (1999) Evaluation of Oil Yield from Jordanian Oil Shales. Energy, 24, 761-781.

[8] Jaber, J.O. and Probert, S.D. (1999) Pyrolysis and Gasification Kinetics of Jordanian Oil Shale. Applied Energy, 63, 269-286. http://dx.doi.org/10.1016/S0306-2619(99)00033-1

[9] Tamimi, A. and Uysal, B. (1990) Parametric Investigation of Oil-Shale Extraction With Organic Solvents. Separation Science and Technology, 25, 1151-1159. http://dx.doi.org/10.1080/01496399008051844

[10] Olukcu, N., Yanik, J., Saglam, M., Yuksel, M. and Karaduman, M. (1999) Solvent Effect on the Extraction of Beypazari Oil Shale. Energy Fuels, 13, 895-902.

http://dx.doi.org/10.1021/ef9802678

[11] Guo, S.H. (2000) Solvent Extraction of Jordanian Oil Shale Kerogen. Oil Shale, 17, 266-270.

[12] Koel, M., Ljovin, S., Hollis, K. and Rubin, J. (2001) Using Neoteric Solvents in Oil Shale Studies. Pure Applied Chemestry, 73, 153-159. http://dx.doi.org/10.1351/pac200173010153

[13] Torrente, M.C. and Galan, M.A. (2011) Extraction of Kerogen from Oil Shale (Puertollano, Spain) with Supercritical Toluene and Methanol Mixtures. Industrial \& Engineering Chemistry Research, 50, 1730-1738. http://dx.doi.org/10.1021/ie1004509

[14] Shawaqfeh, A. and Al-Harahsheh, A. (2004) Solvation of Jordanian Oil Shale Using Different Organic Solvents by Continuous Contact Mixing. Energy Sources, 26, 1321-1330. http://dx.doi.org/10.1080/00908310490442024

[15] Anabtawi, M. and Uysal, B. (2009) Extraction of El-Lajjun Oil Shale. Separation Science and Technology, 30, 3363-3373.

[16] Matouq, M., Koda, S., Maricela, M., Alayed, O. and Tagawa, T. (2009) Solvent Extraction of Bitumen from Jordan Oil Shale Assisted by Low Frequency Ultrasound. Journal of the Japan Petroleum Institute, 52, 265-269. http://dx.doi.org/10.1627/jpi.52.265

[17] Allawzi, M.A., Awni Al-Otoom, A., Allaboun, H., Ajlouni, A. and Nseirat, F. (2011) CO2 Supercritical Fluid Extraction of Jordanian Oil Shale Utilizing Different Co-Solvents. Fuel Processing Technology, 92, 2016-2023. http://dx.doi.org/10.1016/j.fuproc.2011.06.001

[18] Alnawafleh, H.M. and Fraige, F.Y. (2015a) Shale Oil Solvent Extraction of Central Jordan El-Lajjun Oil Shale. Journal of Analytical Sciences, Methods and Instrumentation, 5, 35-43.

[19] G-Hourcade, M.L., Torrente, C. and Galán, M.Á. (2007) Study of the Solubility of Kerogen from Oil Shales in Puertollano, Spain, in Supercritical Toluene and Methanol. Fuel, 86, 698705.

[20] Ebrahiem, E.I. (2002) An Investigation on Solvent Extraction of Oil from Egyptian OilShale. Alexandria Engineering Journal, 41, 579-586.

[21] Abourriche, A., Oumam, M., Hannache, H., Adil, A., Pailler, R., Naslain, R., M. Birot, M. and Pillot, J. (2009) Effect of Toluene Proportion on the Yield and Composition of Oils Obtained by Supercritical Extraction of Moroccan Oil Shale. The Journal of Supercritical Fluids, 51, 24-28. http://dx.doi.org/10.1016/j.supflu.2009.07.003

[22] Alnawafleh, H.M. and Fraige, F.Y. (2013) Characterization of South and Central Jordan Oil Shales. European Journal of Scientific Research, 102, 589-595.

[23] Alnawafleh, H.M. and Fraige, F.Y. (2015b) Analysis of Selected Oil Shale Samples from El-Lajjun, Central Jordan. Geomaterials, 5, 77-84. http://dx.doi.org/10.4236/gm.2015.53008

[24] Al-Alla, R.A. and Nassef, E. (2015) Extraction of Oil from Egyptian Oil Shale. Journal pf Petroleum and Environmental Biotechnology, 6, 205. 
[25] Nassef, E., Soliman, A., Al-Alla R.A. and Eltaweel, Y. (2015) Experimental Study on Solvent Extraction of Quseir Oil Shale in Egypt. Journal of Surface Engineered Materials and Advanced Technology, 5, 147-153. http://dx.doi.org/10.4236/jsemat.2015.53016

Submit or recommend next manuscript to SCIRP and we will provide best service for you:

Accepting pre-submission inquiries through Email, Facebook, LinkedIn, Twitter, etc. A wide selection of journals (inclusive of 9 subjects, more than 200 journals)

Providing 24-hour high-quality service

User-friendly online submission system

Fair and swift peer-review system

Efficient typesetting and proofreading procedure

Display of the result of downloads and visits, as well as the number of cited articles Maximum dissemination of your research work

Submit your manuscript at: http://papersubmission.scirp.org/ 